IDEAS IN ECOLOGY AND EVOLUTION 14: 34-39, 2021

doi:10.24908/iee.2021.14.5.e

(C) 2021 The Author

Received 18 Oct 2021; Accepted 8 November 2021

Guest Editorial

\title{
How I became one of the world's top experts on fire research: despite all, when preparation meets opportunity, truth in science emerges
}

\author{
Byron B. Lamont \\ Byron B. Lamont (B.Lamont@curtin.edu.au),Ecology Section, School of Molecular and Life \\ Sciences, Curtin University, Perth, WA 6003, Australia
}

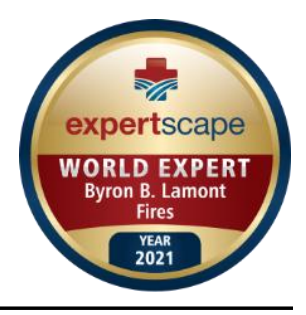

I have a personal story to tell. I never expected that I would get an externally motivated reason to tell it. The outcome has generally been a happy one, but the journey involved adversity, frustrations, and setbacks. These in turn generated motivation, opportunities, and creativity that enabled the development of ideas, with some important lessons to be learned along the way about how truth in science may be pursued. After all, even a bush covered in vicious prickles can produce stunning, perfumed roses. (I am a botanist so I suppose that metaphor appeals to me).

I start with one happy outcome: among all researchers who published scientific articles about fire in the period 2011-2021, I have just (October 2021) been ranked sixth in the world, and my colleague and longtime co-author, Dr Tianhua He, was ranked nineteenth (https://expertscape.com/ex/fires). Only five scientists, among the 21,000 who have published papers with fire in its title over the last ten years, apparently have had more impact than I on the research outputs of those who study fire. As a result, the journal-publishing house, PubMed, designated both of us as "world experts on fire research" since we are in the top $0.1 \%$ of such scientists. One might wonder how we achieved this unexpected ranking - and might suppose that I supervised a large research team supported by impressive Government grants concerned about how to deal with the increasingly devastating wildfires in Australia.

The actual story however is very different. It begins in 2009, when a retired zoologist heard my colleague, Prof. Neal Enright of Murdoch University, give a talk about our recent work in the Eneabba sandplain, $300 \mathrm{~km}$ north of Perth, Western Australia. We had been studying the plant community dynamics of this species-rich shrubland in relation to fire since 1984. I have coauthored 54 papers and co-managed eight research grants with Neal since then; during the 1990s we were described by a project reviewer as the most productive plantecology research team in Australia. Working with the Department of Conservation and Land Management (as it was known then-its current name is Department of Biodiversity Conservation and Attractions) and local fire managers, we had implemented a number of experimental burns at different times since the last fire. We then monitored how the vegetation recovered, especially the establishment and survival of seedlings. This work had shown that the shrubland was not recovering well if burnt at less than ten-year intervals, especially among species killed by fire (Enright et al. 2014). On learning this, the zoologist decided that this showed the flora was not adapted to fire. Because of its important management implications, he approached Neal with a proposal to review plant responses to fire (such as on-plant seed storage, resprouting and fire-stimulated flowering) to show that they were indeed not adapted to fire. They were only apparently so: Mediterranean-type floras were more likely adapted to summer heat and drought, and fire appeared later as just an extreme form of summer stress that the plants were already able to tolerate. Such apparent adaptations are called exaptations, a concept famously introduced by Gould and Vrba (1982).

Neal decided that the review should be broken into various components representing different aspects of plant responses to fire. In 2010, he invited me to look at fire-stimulated flowering and resprouting. He chose flammability and on-plant seed storage (serotiny) as his topics. I asked my research assistant, Dr Katherine Downes, to examine the biology of hard, soil-stored 


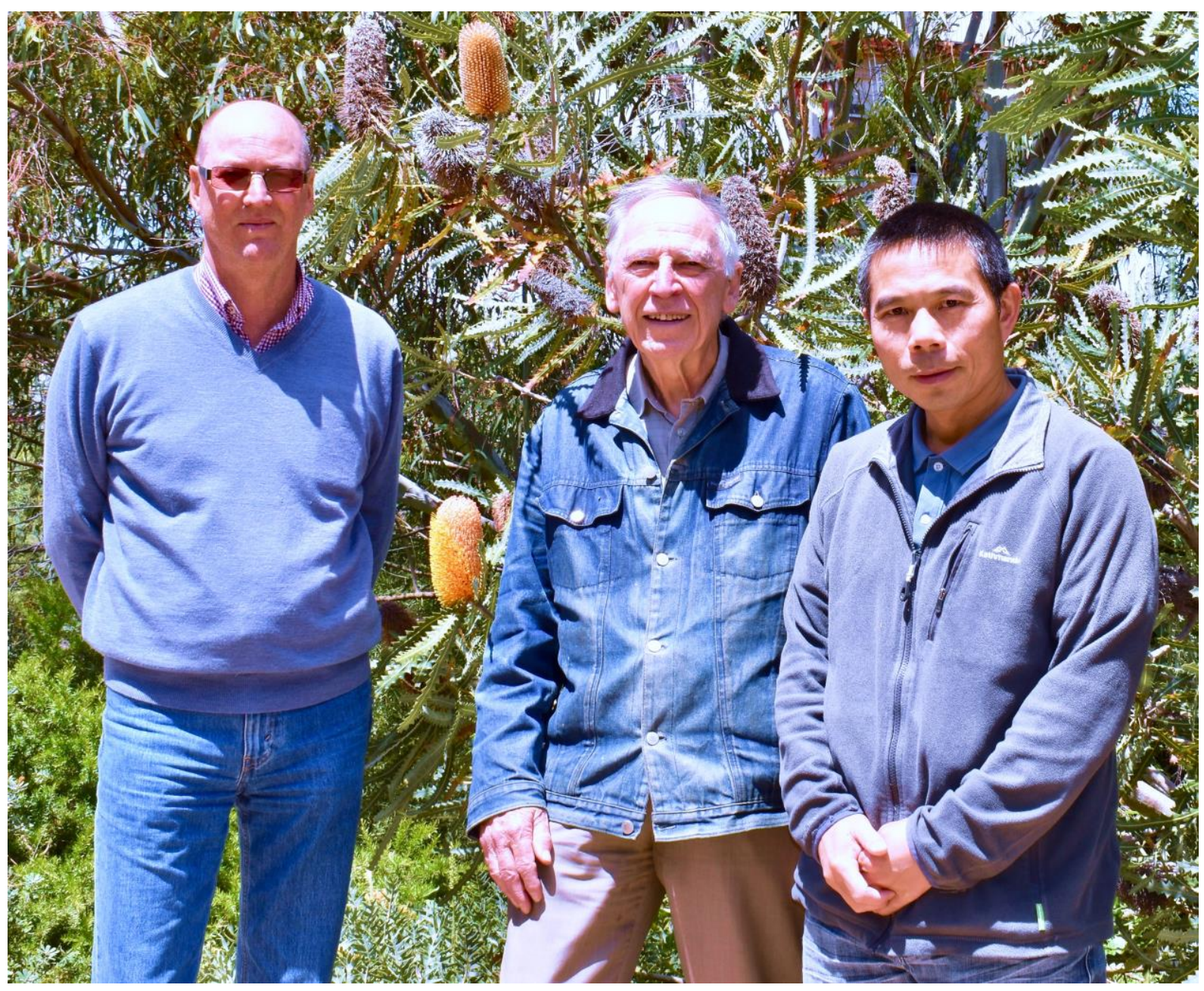

Photo of the three main players in this story with a species of Banksia in the background that provided the early context for this story (all three are now considered world experts on fire research: in the uppermost $0.2 \%$ of those who have published on fire over the last ten years) - left: Neal Enright, centre: Byron Lamont, right: Tianhua He

seeds in relation to fire. I suggested that an expert on plant evolution be asked to participate. Later, a specialist on soft, soil-stored seeds whose dormancy is broken by smoke was added. I spent three months reviewing the literature and writing up my sections. As a good scientist, I tried to be as even-handed as possible, pointing out, for example, that there were many sources of severe damage to plants besides fire, such as frost, drought, cyclones, herbivory, so that plants that resprout after fire cannot be considered to be uniquely adapted to fire.

The result was seven sections on fire responses by the four botanists, a large introduction on what it means to be adapted rather than just exapted to fire by the zoologist as lead author-and a discussion at the end by the lead author that highlighted the divergence of responses and lack of evidence to support unique adaptations to fire. The zoologist decided it was too large to get published in its current form (possibly on advice from a reviewer who appeared as an additional author later). He then cut it back severely, in what can only be described as bias against any evidence supporting fire adaptations, thus becoming more consistent with his concluding discussion that had little support in the original version.

I was alarmed by these conclusions that I did not think reflected our findings accurately and, if the document had to be cut back, those best placed to do so would have been the authors of each section. It was clear to me that attempts to answer the question about adaptations to fire were premature anyway; it was little more than speculation. I asked Neal and Katherine to accompany me in withdrawing from the manuscript with the instructions that our contributions not be used for any future publication without our consent. Hence our surprise in early 2011 to find that an opinion piece 
claiming little evidence for fire-adapted plant traits among species of Mediterranean climate regions appeared in a prestigious review journal. This was coauthored by the same zoologist and two other authors on the original manuscript, plus the person who had reviewed an earlier version, and a fifth person employed at the second author's institution. All the original topics, the papers we reviewed, and their sequence were retained. We were not mentioned in the Acknowledgements.

We tried to get the review withdrawn but we were told that it was too late. We penned a rebuttal but a group of bona fide fire ecologists had already submitted a reply (Keeley et al. 2011-which has since been cited 724 times (Google Scholar, 24 Nov 2021 date)), and the editor declined to consider a second response. The 'exaptation' review has received 183 citations, mostly pointing to it as an alternative view on the topic of fire adaptations. The journal later added a corrigendum (Trends in Plant Science, vol 16, p 177) stating that we were involved "significantly" in earlier contributions to the paper, some (most!) of which was "inadvertently included" in the manuscript. An alert to this note was not appended to the article nor is it referred to in the version that the authors added to ResearchGate.

I was extremely distressed by this development and my health suffered as I tried to come to terms with it (plus the effects of another incident noted below). Trying to refocus on the issue creatively rather than vindictively, I felt that there must be some way to pursue the issue of plant trait evolution in the presence of fire. Although I am essentially a plant ecologist/ecophysiologist, I have an interest in genetics and had employed Tianhua $\mathrm{He}$ as a postdoctoral fellow on a project quantifying longdistance seed dispersal and its role in the metapopulation dynamics of plants in 2004-2009 that used genetic markers to trace adults and their offspring (first paper was He et al. 2004). So I asked him if he was aware of any way of tracing traits such as seed storage and resprouting back in time using evolutionary 'trees' (phylogenies). Tianhua replied that there was a new technique called ancestral trait assignment using probability theory with which he was familiar but it had never been used on firerelated traits.

So, even though I no longer employed Tianhua, we began work on the genus Banksia that I had studied for 30 years and was the focus of our previous long-distance dispersal work. I compiled the fire-related traits and he created the molecular phylogeny and traced the presence of these traits through time using the probability technique. Within six months, we had published a paper in a high-ranking journal called "Banksia born to burn" (He, Lamont and Downes 2011), that a colleague described as the best title for a paper ever! This was accompanied by a commentary authored by two wellknown plant ecologists, Profs Jeremy Midgley and
William Bond (who occupies fifth place in the new fire research rankings) entitled: "Pushing back in time: the role of fire in plant evolution" (Midgely and Bond 2011). Our paper has now been cited almost as much as the 'exaptation' review even though it is on a much more specific topic.

But our paper received strong objections from a wellknown morphologist/paleontologist also interested in the fossil history of Banksias. He claimed that we had used the wrong part of the phylogeny in assigning the onset of adaptations to fire at about 62 million years ago when we should have used the point where the ancestral Banksia first produced daughter species, at the much younger age of 45 million years ago. This researcher was most concerned about the 'error' as he feared that the paper would be highly cited (because of its controversial title?) so he copied his message to many other botanists to alert them to the 'problem'. Luckily, Tianhua and I had already thought about this issue and I took it as my task to respond to the criticism in an intense email exchange. Our logic was that if a species has a trait at the time it is recognized as a species it also had that trait since the time it separated from its sister species (called the stem), as its DNA was not considered to have changed during that period. [Actually, this interpretation continues to be controversial and is unresolvable with current phylogenetic techniques - we dealt with it to the satisfaction of one editor by putting the date in the middle of the stem! (Pausas et al. 2018)]. As this incident occurred about the same time as publication of the 'exaptation' review, my health then became affected by both sources of stress. But I soon recovered and concentrated even more on my research endeavours.

When given the opportunity, we encouraged our critics to pursue research that would test our findings. Thus, four years later, this same paleontologist went on to show, with colleagues, the presence of Banksia fossils together with charcoal at an age somewhat older than 62 million years in central Australia (Carpenter et al. 2015). In fact, all of our older dates for other groups of plants that we studied using the lower, rather than upper, 'node' to identify the time of origin of certain traits were later supported by fossil evidence [e.g., Falcon-Lang et al. (2016) and Mays et al. (2017) in reference to He et al. (2012)]. So, we did not get the interpretation wrong after all. Part of the explanation is also that fossils, which are used to set the molecular clock, will always be younger than the actual ancestor of the clade, so the tendency will always be to underestimate age of taxa at the nodes.

Luckily, Neal Enright, as chief editor of the journal, Plant Ecology, had decided to produce a special issue on resprouting in 2011 and we were able to extend our literature reviews and further develop our ideas raised in our anonymous contributions to the exaptation review, and published three papers in that issue (Lamont and Downes 2011, Lamont, Enright and He 2011, Enright et 
al. 2011). These have been cited together 317 times (these outputs, and many others, were not used in the assessment of fire 'experts' by PubMed, which only included journals that it considered relevant to medicine). I am especially proud of the review I produced with Katherine Downes on fire-stimulated flowering because it provides irrefutable evidence of plant adaptations to fire where there might be a bit of ambiguity with some other traits; some plants only flower in response to fire and may even lie dormant in the soil until the next fire.

By now we had begun a project on pines that dominate the forests of Europe, North America and nontropical parts of Asia. Tianhua assembled experts on the fire ecology of pines in the USA, Spain and UK. He prepared a phylogeny and converted it into a chronogram using the so-called molecular clock, based on the rates at which DNA changes through time. Using ancestral trait assignment techniques, Tianhua showed that this genus had been subjected to fire for about 134 million years and that special adaptations to fire, such as heat-released seeds from the familiar pine cones, arose about 99 million years ago. The manuscript was submitted to the prestigious Proceedings of the National Academy of Sciences (PNAS) based in the USA. It was rejected without review by the editor, a decision we found surprising because of the great relevance of this work to the history of such an iconic tree in the USA, where it is the mainstay of forestry. So we submitted it to the equally prestigious British journal, New Phytologist, that readily accepted it (He et al. 2012). It has now been cited 217 times.

This raises the issue of the judgement process of highranked journals such as PNAS: they are pre-occupied with maximizing their citation rates, and their prestige is partly gauged by the percentage of manuscripts that they reject (e.g., it is about $95 \%$ for Nature), and they give the acceptance rate on their websites. In the past, submitted manuscripts were routinely sent out for review but now the submission rates are typically five times what the journal can publish (or are willing to publish), and reviewers are hard to find (they do their highly demanding task for nothing after all and I know of no scientist whose job description includes assessing external manuscripts for their 'publishability'). Consequently, editors now consider themselves as oracles to streamline the process, which has its own problems (Farji-Brener and Kitzberger 2015). They have to guess what will be the most highly-cited papers and only send those out for review ("this is not to be taken as judgement on the scientific merit of your work" they say in their rejection letters).

As an aside, I was delighted to see that one of the authors of the 'exaptation' paper stated four years later (Flematti, Dixon and Smith 2015) that "Fires have been a feature of the Earth since land plants evolved... responses of seed plants to fire probably evolved mainly in the 'fiery' Cretaceous period... when conifers dominated and Angiosperms were evolving rapidly (He et al. 2012)". So he must have had second thoughts on viewing our findings. According to Planck's (1950) principle (Hull, Tessner and Diamond 1978), ideas don't change in science; it is just that old scientists die! As a 76-year-old myself, I am an example of how this ageism has no basis in fact, as some of my colleagues regard my published outputs since retirement in 2010-many based on novel ideas-as the most influential of my 50-year career.

Some of the data we acquired were used in the review Lamont and He (2017) published in the same journal as the 'exaptation' review. This showed that species were usually fire-prone before the evolution of fire-adapted traits, negating the argument that they were simply exaptations. More recently, Tianhua and I were coauthors of a paper on "Biological and geophysical feedbacks with fire in the Earth system" (Archibald et al. 2017) with 100 citations so far. Prof. Sally Archibald is listed third on the list of so-called fire experts. We were invited to the associated workshop in South Carolina on grounds of our reputation in research on the historical links between fire and plant traits (other participants were from Australia, Spain, USA, Britain, South Africa, South America). I also used some of our data in a review on "Unearthing belowground bud banks in fire-prone ecosystems" (Pausas et al. 2018, with co-authors from Spain and Brazil) that is currently receiving over 50 citations per year. The lead author, Juli Pausas, who is listed second among the fire experts, commented that without the evolutionary dimension that our work provides he doubts that it would have gotten into such a highly-ranked journal. Other recent outputs include "Fire and plant diversification in Mediterranean-climate regions" (Rundel et al. 2018) with authors from California, Mediterranean Basin, South Africa and Australia (cited 52 times so far but not included in PubMed's list).

What is proving to be one of our most influential papers is He, Lamont and Pausas (2019) "Fire as a key driver of Earth's biodiversity", that has already been cited 125 times in the 20 months since publication. Our most recent review/commentary was published last year in the present journal (Lamont and He 2020). Here, we argued that fire, as the major form of ad hoc disturbance, should hold equal status with the standard variables assessed in ecology and evolutionary biology: the fixed environment (climate, soils, light, nutrients, topography) and biotic interactions (competition, granivory, allelopathy, pollination, herbivory). This was an elaboration on the idea of fire as the third dimension among constraints with which plants must adapt that was the insight of our Spanish colleague, Juli Pausas (Pausas and Lamont 2018). Overall, my top 15 fire papers over the last 10 years had 
been cited over 2000 times by 24 November 2021 . So it is pleasing, indeed a relief, that I have not been wasting my time since official retirement.

Are there lessons from my story for other researchers? I am not sure. But we are told that optimists are happier people! Creativity starts when preparation meets opportunity (the original saying referred to luck, that might also apply here- "it is not what you know but who you know"-medium.com/@RationalBadger/luckpreparation-opportunity-1d68a43655f2). My expertise lies with fire ecology and fire-related plant traits (preparation). But I know my limits and already had a good working relationship with an excellent geneticist competent in tracing the evolution of plants and who was prepared to undertake the necessary research with me (opportunity). I overcame the outrage and distress of omission from a manuscript that I had worked on for three months by turning it into a desire for actual answers rather than biased speculation. Perhaps I was motivated to get my own back in a rather obtuse way?! Tianhua and I were thankful to receive two grants from the Australian Research Council to work on the problem.

But our success created, or consolidated, too many enemies. Some biologists in key positions did not like what we were finding. Despite our enormous published outputs on a per capita basis, our subsequent five attempts to secure further funding on related topics, such as the role of fire as a mutagenic agent, came to nothing. Our literature survey showed that heat and combustion products from fire could actually cause mutations to occur in plants (He and Lamont 2018); that it could be an evolutionary force is a tantalizing idea that deserves indepth examination. Our team was too small, despite wide international contacts, and so was easily dismissed. Research oligarchies that universities pour millions of dollars into, and even create special buildings for, are the way that one develops a research reputation on the international scene it seems. It reminds me of the current approach of some editors in picking 'winners'!

Tianhua moved from Curtin to Murdoch University in 2018. He now works on the genetics of grain crops as there are better funding opportunities in the agricultural industry. When you lack influential colleagues (supportive friends in high places), don't get research grants from prestigious competitive bodies like the Australian Research Council, and the institution is channelling its limited funds into 'preferred' research groups, your research future is limited. Luckily, none of that was relevant to me-I was already retired during the 2011-2021 period and received no university funds during this period, even as a ('distinguished') emeritus professor who was expected to maintain research links with the university. I am a very creative person and my research over the last ten years has been a wonderful outlet for this creativity, if frustrating at times (e.g. rejections of manuscripts by one journal after another make me think I must be a masochist sometimes). I do not need much money other than to pay to get my work published through the new perk for journal publishers called "open access" (does it really add thousands of dollars to the cost of publishing this way that must be retrieved from the hapless researcher, or is it just a new way for journals - the present journal being an exception-to make money?), and perhaps a bit of technical assistance that I pay for myself.

I just plod along; research is, and has always been, my hobby. With a 16-hour teaching week before retirement, I had to fit it in outside my normal working week unless on sabbatical leave. I love the fieldwork, analysing data, collating the literature, seeking support for a hypothesis that has occurred to me (I don't have the stress of needing to satisfy the objectives of a formal research project anymore, nor giving the work over to postgraduates who may or may not embrace it with the same enthusiasm), preparing tables, graphs and illustrations (I find these extremely fulfilling activities as they satisfy my artistic tendencies), and preparing the manuscript (my ability to write has always been one of my strengths; actually biology is all about writing) - I do it all and relish in it! But I know my limits in this highly complex research world and it is taxing to have to constantly ask for favours from specialists rather than they be paid members of my team. I owe a huge debt to my many academic colleagues with whom I have worked over the last 50 years, most of whom were never employed by me. Progress in research now is entirely dependent on my own initiatives and energy and it can wear thin at times.

Perhaps I should have built up a team of postdocs with millions of dollars to pay them (the modern way to go!), who would do all these things for me and I would just add my name to the manuscript at the end, as is now the common practice-heads of research teams know that they have to do it otherwise their funding would stop and they would no longer be in charge of a research oligarchy; ultimately it is an ego thing. Then perhaps I would be listed number one instead of number six among the world's 21,000 fire researchers? But then perhaps not. Besides, I am not a science entrepreneur-I do not enjoy managing people and have always been a bit of a loner, a thinker, an astute observer, inquisitive about how nature works-I prefer to be at the coalface. I am happy with what I have achieved in my retirement. Despite the setbacks, truth in science has prevailed.

But it is not clear from this story that science is a just world any more than any other area of human endeavour. The imperative to publish whatever the circumstance, to suppress competitors by denying them funds or tenure, the omniscience of editors and funding bodies in their choice of 'winners', failure to recognize or foster individual creativity, to judge success by the number of publications in Nature, size of grants and of the research team, and the quest by university management for 
research prestige whatever the cost. These are spurious measures of success in the quest for truth and are not pathways that favour equity in science.

\section{Acknowledgements}

I thank Neal Enright and Tianhua $\mathrm{He}$ for valuable comments on the manuscript, and Lonnie Aarssen for encouragement and helpful editorial comments, but I take full responsibility for all statements made here.

\section{References}

Archibald S., Lehmann, C.E.R., Belcher, C.M., Bond, W.J., Bradstock R.A., Daniau, A-L., et al. 2017. Biological and geophysical feedbacks with fire in the Earth system. Environmental Research Letters 13: 033003. CrossRef

Carpenter, R.J., Macphail, M.K., Jordan, G.J., and R.S. Hill. 2015. Fossil evidence for open, Proteaceaedominated heathlands and fire in the Late Cretaceous of Australia. American Journal of Botany 102: 20922107. CrossRef

Enright, N.J., Fontaine, J.B., Westcott, V.C., Lade, J.C., and B.P. Miller. 2011. Fire interval effects on persistence of resprouter species in Mediterraneantype shrublands. Plant Ecology, 212: 2071-2083. CrossRef

Enright, N.J., Fontaine, J.B., Lamont, B.B., Miller, B.P., and V.C. Westcott. 2014. Resistance and resilience to changing climate and fire regime depend on plant functional traits. Journal of Ecology 102: 1572-1581. CrossRef

Falcon-Lang, H.J., Mages, V. and M. Collinson. 2016. The oldest Pinus and its preservation by fire. Geology 44: 303-306. CrossRef

Farji-Brener, A.G., and T. Kitzberger. 2015. Are editors of ecological journals good oracles? A reply to Schimel et al. (2014) about the malpractice of editorial rejections. Ideas in Ecology and Evolution 8: 1-6. CrossRef

Flematti, G.R., Dixon, K.W., and S.M. Smith. 2015. What are karrikins and how were they 'discovered' by plants? BMC Biology 13: 1-7. CrossRef

Gould, S. J., and E.S. Vrba. 1982. Exaptation - a missing term in the science of form. Paleobiology 8: 4-15. CrossRef

He, T., and B.B. Lamont. 2018. Fire as a potent mutagenic agent among plants. Critical Reviews in Plant Sciences 37: 1-14. CrossRef

He T., Lamont, B.B., and K.S. Downes. 2011. Banksia born to burn. New Phytologist 191: 184-196. CrossRef

He, T., Krauss, S., Lamont, B.B., Miller, B.P. and N.J. Enright. 2004. Long-distance seed dispersal in a metapopulation of Banksia hookeriana inferred by population allocation analysis from AFLP data. Molecular Ecology 13: 1099-1109. CrossRef

He, T., Lamont B.B. and J.G. Pausas. 2019. Fire as a key driver of Earth's biodiversity. Biological Reviews 94: 983-2010. CrossRef

He, T., Pausas, J.G., Belcher, C.M., Schwilk, D.W. and B.B. Lamont. 2012. Fire-adapted traits of Pinus arose in the fiery Cretaceous. New Phytologist 194: 751759. CrossRef

Hull, D.L., Tessner, P.D., and A.M. Diamond. 1978. Planck's principle. Science 202(4369): 717-723. CrossRef

Keeley J.E., Pausas J.G., Rundel P.W., Bond W.J., and R.A. Bradstock. 2011. Fire as an evolutionary pressure shaping plant traits. Trends in Plant Science 16: 406-411. CrossRef

Lamont, B.B. and K.S. Downes. 2011. Fire-stimulated flowering among resprouters and geophytes in Australia and South Africa. Plant Ecology 212: 21112125. CrossRef

Lamont, B.B. and T. He. 2017. Fire-proneness as a prerequisite for the evolution of fire-adapted traits. Trends in Plant Science 22: 278-288. CrossRef

Lamont, B.B. and T. He. 2020. The third dimension: how fire-related research can advance ecology and evolutionary biology. Ideas in Ecology and Evolution 13: 25-56. CrossRef

Lamont, B.B., Enright N.J. and T. He. 2011. Fitness and evolution of resprouters in relation to fire. Plant Ecology 212: 1945-1957. CrossRef

Mays C., Cantrill D.J. and J.J. Bevitt. 2017. Polar wildfires and conifer serotiny during the Cretaceous global hothouse. Geology 45: 1119-1122. CrossRef

Midgley, J.J. and W.J. Bond. 2011. Pushing back in time: the role of fire in plant evolution. New Phytologist 191: 5-7. $\underline{\text { CrossRef }}$

Pausas J.G., and B.B. Lamont. 2018. Ecology and biogeography in 3D: the case of the Australian Proteaceae. Journal of Biogeography 45: 1469-1477. CrossRef

Pausas J.G., Lamont B.B., Paula S., Appezzato-da-Glória B. and A. Fidelis. 2018. Unearthing belowground bud banks in fire-prone ecosystems. New Phytologist 217: 1435-1448. $\underline{\text { CrossRef }}$ 